\title{
2. ハイビジョン放送体系
}

\section{1. 規格化への歩み}

\section{1 国際規格化の動き}

\section{(1) はじめに}

1990 年 5 月 23 日, ドイツ連邦共和国 (旧西トイツ) のデュッセルドルフて開催された第 17 回 CCIR（国際 無線通信諮問委員会) 総会において, 初めて HDTV のスタジオ規格に対する勧告化が行われた HDTV の研究が CCIR で取り上げられてから実に 18 年の歳 月が過ぎ去っていた

\section{（2） HDTV 研究の登場}

HDTV(ハイビジョン)は, NHKが世界に先駆け て 1970 年頃から研究開発を進めてきたものて, 国際 的にこの問題が登場したのは, 1972 年 CCIR の研究 委員会である SG 11 （テレビジョン放送担当）におい て, 我が国がHDTVを提案し, 研究計画(SP) とし て採用されたときからであるその後, 1974 年の第 13 回総会において HDTV は研究課題 (Question) 27/ 11 として正式に承認され，CCIR の場で検討されるこ ととなった

1978 年の第 14 回総会ては, 我が国の貢献により初 めて HDTVの現状がレポート 801 としてまとめら れ，勧告化への長い道程の第一歩を印すこととなっ たこのレポートは, 1982 年の第 15 回総会てその後 の現状を加味されて 801-1 と改訂された

(3) 第 16 回 CCIR 総会

（a） CCIR IWP（中間作業班）11/6 の設立 1983 年のSG11の中間会議において, IWP $11 / 6$

\footnotetext{
†郵政省 放送行政局 技術課

†郵政省 放送行政局 衛星放送課

"H1-Visıon Broadcastıng" by Masataka Kawauchı (Eng1 neerıng Division, Bradcastıng Bureau, Minıstry of Posts and Telecommunications, Tokyo) and Makoto Sugiura (Satellite Broadcastıng and HDTV Divisıon, Broadcastıng Bureau, Ministry of Posts and Telecommunications, Tokyo)
}

河内 正 孝 ${ }^{\dagger}$ 杉浦 誠 ${ }^{\dagger+}$

（高精細度テレビジョン標隼）が設立されたことによ り, 勧告化への作業が本格化したこの作業班は, HDTVのスタジオ規格を勧告案としてまとめ, 総会 に提出することを任務とし，このための作業として， 走査線数, 画面のアスペクト比等のパラメータのほ か, HDTV 技術が映画, 印刷, 医㞠等の非放送分野 にも応用が可能か等について検討を行うこととなっ た作業班は, HDTVのスタジオ規格の勧告化まて に 10 回の会議を重ねたが, この重責を担う議長は, 我が国から NHKの田所 康(現池上通信機) 氏が選 任された

1985 年 9 月の第 4 回 IWP 11/6の会合で, 我が国 は長年の研究成果を基に, 米国, カナダと共同で我が 国の 1125/60 方式を世界統一規格として採用するよう 正式に CCIRに提案し, 翌月に開催されたSG 11 の 最終会議で「新勧告の提案」として採択された

(b) 第 16 回 CCIR 総会

HDTV 問題が国際的に大きな注目を浴びたのは, 1986 年 5 月, ユーコススビアのドブロブニクで開催 された第 16 回総会であったこの会議で日本, 米国, カナダは, 先の最終会議で採択された新勧告の提案に 基づき, HDTVの早期勧告化を主張したしかし, フランス, オランダをはじめとする欧州諸国は, 勧告 は時期尚早として反対したため, 勧告は 1990 年の総 会まで延期された とはいえ, 我が国の 1125/60 方式 は, 唯一の提案として,レポート801-2の付録に 「HDTV スタジオ信号パラメータの新勧告の提案」と して記載された

もともと, CCIRにおける研究は, 技術面の検討を 重視していたが, この総会以降, 各国の利害がからん だ政治色を帯びたものになっていったこの背景に は, 将来, 民生電子機器市場で大きな市場と期待され るHDTVをめぐって, 強い国際競争力をもつ日本に 自国の市場が席巻されるという危機感が欧州側にあっ たといわれている このため, オランダのフィリップ テレヒジョン学会誌 Vol 45, No 11,pp 1332 1336 (1991) 
スやフランスのトムソン等のメーカは, 欧州放送連合 (EBU) が新勧告の提案を賛成したにもかかわらず, EC 委員会に勧告の阻止を強く働きかけた.

（4）第 17 回 CCIR 総会

(a) 第 16 回 CCIR 総会後の欧米の動向

第 16 回 CCIR 総会で日本方式での勧告化を阻止し た欧州は, 1986 年 EC 委員会を中心にメーカ, 大学, 放送事業者の合わせて 32 の機関で構成する「ユーレカ 95」計画をスタートさせ, 欧州独自の HDTV 開発に 着手した. 欧州は, 1987 年 11 月の SG 11 中間会議で 欧州方式 1250/50 の勧告を提案した.

日欧が対立する図式のなか，これまで我が国と歩調 を合わせていた米国は，日米貿易不均衡に対するいら だち，HDTV 開発の遅れが民生部門だけでなく，自 国の安全保障にも影響しかねないという危機感等から 議会, 産業界等を中心に自国産業の保護, 育成の声が 高まり，独自方式の開発路線を歩み始めることとなっ た．その影響もあってか, ATSC (米国次世代テレビ 方式委員会)は, SMPTE(米国映画テレビ技術者協 会)が, 1987 年 8 月米国標準 $240 \mathrm{M}$ として認めた日本 方式を，いったん米国方式と承認したが 1989 年 4 月 撒回した。

これにより, HDTV 問題は一層混迷の様相を呈し， 第 17 会期 (1986〜1990 年)での HDTV のスタジオ規 格の勧告化が危ぶまれる事態となっていった．

こうしたなか, CCIR では, カービー委員長やクリ ボチェフ SG 11 議長が中心となって各国に第 17 会期 中での HDTV の勧告化を説得した結果，1989 年 5 月 に HDTV 問題だけを審議する SG 11 の特別会議が開 催されることとなった．

\section{（b） CCIR SG 11 特別会議}

1989 年 5 月, HDTV のスタジオ規格の勧告化案等 の作成を目的にジュネーブでSG 11 の特別会議が開 催された。この会議では, 個別の項目ごとに検討を加 え, 日欧両方式の対立点となっていない画面のアスペ クト比や水平方向のサンプル数等, 合意できるものか ら処理する審議方法を採用した。

この会議で米国から，第 17 会期中に統一規格がで きないならば勧告を 1994 年の第 18 会期（1990～1994 年）まで延期してほしいとの公式表明がなされたが， 対立点をひとつひとつ解決していく形で勧告化案作り が前進し，34 項目のうち 18 項目が合意され，HDTV スタジオ規格の勧告化案 $(\mathrm{XA} / 11)$ のほか $3 \supset$ つ HDTV 関係の勧告化案が作成された。

なお，日欧が対立するなかで，両方式の方式変換を 容易にするための手法として，スウェーデン，カナダ
からコモンイメージフォーマット (CIF) という概念が 提案された. CIF の考え方は, 画面のアスペクト比 (16：9), 有効走查線数 (1080 本), 水平方向のサンプ 儿数 (1920 本) を共通化するもので, 我が国は, 有効 走査線数 1035 本を提案していたが，国際的に統一さ れることを条件にCIF を支持した。一方，欧州側は， コモンデータレート (CDR：複数規格を前提に単位時 間当たりのデー夕量を共通するよう規格項目を決定す るもの)を主張した。

(c) CCIR SG 11 最終会議

5 月の特別会議に引続き, 1990 年 5 月の総会に向 けて懸案となっているHDTV スタジオ規格等を検討 するため, 1989 年 10 月，ジュネーブで SG 11 最終会 議が開催された。我が国は，1125/60 方式を基本とし ながらも，今会期での勧告化を目指し，合意できる項 目数の増大に努める方針で会議に臨み，精力的に各国 との個別協議をも重ねた。その結果，項目整理が行わ れ， 27 項目中 23 項目 (留保付き 4 項目を含む)につい ては統一化された数值で，4 項目については文章表現 での勧告草案（XA/11）を改訂したほか，新たに一つ の勧告化案を作成, 先の最終会議での 3 つの勧告化案 を加えた 5 つの勧告案を 1990 年 5 月の総会に提出す ることが合意された。

\section{(d) CCIR IWP 11/6}

1990 年 3 月, 先の最終会議で持ち越された勧告草 案 XA/11 の有効走査線数および留保付きの項目を審 議するため, IWP 11/6 会議が開催された。

欧州側は, 留保していた 3 原色の色度点, 輝度信号 方程式および色差信号方程式の 3 項目について, 最終 会議での勧告案と異なる数値を採用するよう主張した が，これに対する検証が不充分であり，数值自体も不 適当であることから，日本，米国，カナダは反対し た. 結局, 勧告案は, 現在の技術に基づく数值と位置 付け，欧州側提案は，将来の技術に基づく検討事項と して付録の中に例示することで合意が成立し，留保が 解除された。

有効走查線について，我が国は，国際的に合意され ることを条件に $\mathrm{CIF}(1080$ 本)を支持し，米国，カナ ダもニュアンスは異なりながらも支持した。一方，欧 州側もこれまでどおり CDR を主張したことから議論 が出つくし，あまり大きな議論とならなかったが，ス ウェーデンからコモンイメージパート（CIP：当面は 複数規格を認め, 格子構造等を共通にし最終的に有効 サンプル数 2048, 有効走查線数 1152, 順次走査, 毎 秒の画面数 72 を目標としている)が出され，勧告案の 付録に提案があった旨追記されたほかは，ほほ原案の 
まま総会に提出されることとなった．

(5) 第 17 回 CCIR 総会

1990 年 5 月に開催された第 17 回総会では, これま での日欧の対立から勧告化が危ぶまれるとの見方もあ つたが，あっけなく 5 つの HDTV 関係の勧告を採択 した. HDTVのスタジオ規格の勧告は, 全体で 27 項 目から構成され, 毎秒の画面数, 垂直および水平帰線 消去期間, 有効走查線数, 未合意のディジタル項目の 4 項目については, 統一された数值でなく文章表現と なったが,この勧告化により, 初めて国際的に HDTV 実用化の環境が整備されたものと評価されて いる.

（6）勧告後の動向

(a) CCIR IWP 11/9 会議

IWP 11/9 は, 放送分野と非放送分野との調和を図 るため, 1989 年 SG 11 最終会議で設立され，その第 1 回の会合が 1990 年 10 月, IEC（国際電気標準会 議), ISO (国際標準化機構) 等の非放送分野の代表も 参加して東京で開催された。会議では, アスペクト 比, 走査線数等について非放送分野から多くの要求が 出された。

(b) CCIR TG 11/1 会議

1991 年 2 月, CCIR の組織改正後初の TG 11/1（旧 IWP 11/6) が, 勧告 709 （旧 XA/11）の未確定パラメ 一タの完結等を目的として開催された。会議では, 欧 州諸国から欧州方式 (1250/50/1:1(1920/1152)) での 勧告化の共同提案や $\mathrm{EBU}$ からの最終的に欧州方式で 総一するためのステップとしてのデュアルスタンダー ド化(1125/60/2:1(1920/1080), 1250/50/2:1(2048/ $1152))$ の要求が出されたが, 意見をまとめることは容 易でないとして, 勧告 709 につては, 今回手をつけ ないこととなった。このため, スペシャルラポー夕を 指名し, カラリメトリー, ピクチャーレート, ディジ タル関係について, 第 2 回の会議までにまとめるよう TG 11/1の議長から要請された.

なお，我が国から 1125/60 方式に基づく国内規格を 近く制定するとの報告を行ったが，欧米諸国から特段 コメントや反発は見られなかった。

\section{2 国内規格化の動き}

（1）電波技術審議会

HDTV の国際的な規格化についての研究が CCIR で進められている間に，国内ではこれを放送に適用す るための規格化の研究が開始された。

1984 年 4 月から, 電波技術審議会 (電気通信技術審 会の前身．郵政大臣の諮問機関)において, 諮問第 30 号「高精細度テレビジョン放送に関する技術的条件」
として審議が始まった。

この審議会においては, CCIR の動向に注意を払い つつスタジオ規格について検討を行った．このときの 暫定規格案は, 走查線数 1125 本, アスペクト比 5 ： 3 , インタレース $2: 1$, フィールド周波数 $60 \mathrm{~Hz}$ を一 応の基本パラメータとしていた。

\section{（2）電気通信技術審議会}

1985 年 4 月に電波技術審議会は電気通信技術審議 会(郵政大臣の諮問機関)へと組織改編が行われた. HDTV の規格化に関する審議は電気通信技術審議会 へ諮問第 16 号として引き継がれ, 高精細度テレビジ ヨン委員会で審議が開始された。

スタジオ規格については，CCIRでのスタジオ規格 の基本パラメータとの整合性を重視しつつ, 検討が進 められた。

1985 年 11 月からスタジオ規格に加え, 伝送規格 （送信方式）についても検討が開始された．伝送方式に 関しては, NHKのMUSE方式, 名古屋大学の TAT 方式, NTT の TCM 方式の 3 方式が委員会に 提案されたが, 実用化時期として 1990 年頃が予想さ れたため, 実用段階に最も近いMUSE 方式が採用さ れた。

1988 年 6 月には暫定規格案として, スタジオ規格, 音声方式, 伝送規格に関しての中間報告が出され，こ の規格案に基づく衛星伝送実験が BS-2 を用いて実施 された.

1989 年 2 月から HDTV のデータチャンネル（パケ ット形式で汎用のデータを伝送できる伝送チャンネ ル）および有料方式（有料放送のためのスクランブル サブシステムおよび関連情報サブシステム）について の検討が開始された.NTSCとの整合性を重視し， NTSC のデータチャンネルおよび有料方式に準拠し た方式が採用された。

1990 年 5 月の CCIR 第 17 回総会で勧告案 XA/11 が採択されたことを受け，同年 6 月 25 日に諮問第 16 号「高精細度テレビジョン放送に関する技術的条件」 に対する答申が電気通信技術審議会から出された。こ こに 6 年以上に及ぶ委員会の活動に終止符が打たれ た。答申された規格の内容については 4 章に詳しい記 述があるので, そちらを参照されたい.

（3）制度化

電気通信技術審議会からの答申は, 望ましい規格案 を郵政大臣に対し建議するものであり，そのままでは 規格としての法令上の効力をもたない.このため, 電 波法に基づく郵政省令として 1991 年 3 月 1 日付けで 技術基準が制定され，同日付けで施行されている。 
この技術基準は，「高精細度テレビジョン放送に関 する送信の標準方式」「高精細度テレビジョン音声多 重放送に関する送信の標準方式」および「無線設備規 則」の 3 つの郵政省令から成っている．これらの省令 は，放送衛星 (11.7 GHz 帯) によるハイビジョン放送 に適用される。

高精細度テレビジョン放送に関する送信の標準方式 は，スタジオ規格と放送衛星による送信方式について の技術基準を定めている．送信方式としては，映像と 音声に関する規定のほか, データチャンネルやスクラ ンブル方式についても規定されている．この省令で は, 最大偏移周波数, ライン周波数等, 一定の範囲の 偏差が許容されるものについては, 標準值のみを規定 しており，そこからの許容偏差は無線設備規則で規定 している。

現行制度では, MUSE 伝送方式が有する4つの音 声チャンネルのうち，1つの音声チャンネルのみが高 精細度テレビジョン放送(ハイビジョン放送)に属する ものとし, 残りの 3 つの音声チャンネルは高精細度テ レビジョン放送とは独立したメディアであると見なし て，これを高精細度テレビジョン音声多重放送と呼ん でいる.したがって, 高精細度テレビジョン音声多重 放送に関する送信の標準方式は，ほぼ高精細度テレビ ジョン放送に関する送信の標準方式から映像信号に関 する規定を除いたものとなっている.

無線設備規則では, 放送衛星局に関する一般的規定 がハイビジョン放送を行う放送衛星局にも適用される が, 個別にハイビジョン放送に適用される項目とし て, 同期信号波形の許容範囲，ライン周波数の許容偏 差, 送信設備の周波数特性等, 実際の無線設備が満た すべき技術的条件が規定されている。

HDTVについては技術基準以外の諸規定の整備も 一段落しており，無線局免許制度上，すでにハイビジ ヨン放送が実施可能な状態になっている。

（4）有線放送系の動き

八イビジョンの普及促進のためには, 衛星放送の個 別受信に加えて, CATV (有線テレビジョン放送) 施 設によるハイビジョン放送の共同受信も大きな意味を もつ.このため, 衛星系でのハイビジョン放送の規格 化の動きを受け, CATV 施設でハイビジョンを送る ための規格の検討が進められている.

1990 年 11 月には，電気通信技術審議会に諮問第 68 号「高精細度テレビジョン放送に伴う有線テレビジョ ン放送施設に関する技術的条件」が諮問されている。

ここでの審議では，FM 方式と VSB-AM 方式のそ れぞれについて検討されており，1991年 5 月 27 日に
$\mathrm{FM}$ 方式について一部答申が出されている．この答申 では, FM方式における伝送方式は衛星系と同じ MUSE 方式が採用されている.

この答申については, 有線テレビジョン放送法に基 づく郵政省令として制度化すべく，現在，作業が進め られている。

また, 残る VSB-AM 方式についても, なるべく早 期に答申すべく, 現在, 電気通信技術審議会で審議が 継続されている.

\section{2. 放送実施体制}

前述のように放送衛星によるハイビジョン放送が制 度化されたことにより, BS-3bでは八イビジョン放 送の実施が予定されている。ここでは，現在実施され ている実験放送の経緯を述べたあと, BS-3bでの八 イビジョン試験放送実施の準備状況を紹介し, 最後に 将来のハイビジョン放送の形態の大きな割合を占める と予想される有料放送についての検討状況を紹介す る.

\section{1 実験放送}

放送衛星, 通信衛星を使用したハイビジョンの伝送 実験は，1986 年 12 月に BS-2 b による伝送実験が行 われて以来多数行われて抢り，八イビジョンの放送規 格決定にも大きく寄与してきている.

この中でハイビジョン放送の実施に特に関連が深い のは, NHKが実施しているハイビジョン定時実験放 送であろう。

これは，1989年 6 月 3 日に開始され，以後， 1 日 1 時間ずつ実施されている。この実験は, BS-2 b の衛 星第 2 テレビジョン (11 チャンネル) の放送用中継器 を使用して行われているものであり, 省令化された放 送規格を満たしている。したがって, 実験とはいえ， ハイビジョン放送の実施時に極めて近い状況が実現さ れている.

1990 年 11 月 30 日には, 衛星放送を実施する衛星 が BS-2 b から後継機の BS-3 a に切り替えられたこ とから,この実験も BS-3 a に引き継がれている.

BS-3 a の放送用中継器を使用した実験としては, $\mathrm{JSB}$ (日本衛星放送(株) も 1991 年 2 月 20 日から 2 月 28 日までの 9 日間, ハイビジョンの伝送実験を行っ ている。

このような放送用中継器を使用したハイビジョン伝 送実験は, より多くの人々の関心をハイビジョンに集 めることにも一役買っている.

\section{2 試験放送}

（1）ハイビジョン専用中継器の確保 
ハイビジョン実験放送の次の段階として, 1991 年 8 月に打ち上げ予定の BS-3bでは, 放送用中継器が 確保されハイビジョン試験放送の実施が予定されてい る.

この放送用中継器は, 通信・放送衛星機構が産業投 資特別会計(産投会計) からの出資により確保し, 八イ ビジョン放送を行う者に利用(リース)させることが予 定されている．産業投資特別会計からの出資は，1988 年度から 1991 年度までの合計 75 億円である。

なお，産業投資特別会計は，経済の再建，産業の開 発および貿易の振興のために国の財政資金によって投 資を行うことを目的として設置されている．日本開発 銀行および日本輸出入銀行の納付金, NTT, JT お よび電源開発の配当金等を主な財源としている.

\section{（2）放送普及基本計画の変更}

放送普及基本計画は, 放送法に基づき, 放送の計画 的な普及および健全な発達を図るために定められる計 画であり, 郵政大臣はこれに基づき必要な措置を講ず ることとなっている.

八イビジョン放送の技術基準が制定されたことに併 せ, 放送普及基本計画が変更されている. ハイビジョ ン放送については従来技術開発課題であったものが 「放送衛星 3 号による実用化を図ることとし, このた めの試験放送を行うこと」と変更され, 八イビジョン 放送(試験放送)の実施に努めることが公約されてい る。

\section{（3）試験放送実施主体}

このように, BS-3 b でのハイビジョン放送実施に 向けた環境が整備され, 放送実施主体の早期の登場が 望まれている中で, 今, 新しい組織を作ろうとする動 きがある。

通信・放送衛星機構が所有しているハイビジョン専 用中継器による試験放送を実施するとともに, 従来か らのハイビジョン普及事業を行う組織として, NHK, 放送事業者, ソフト制作者, 八イビジョン関 連機器メー力等から成る社団法人が検討されている模 様である*.

\footnotetext{
* 原稿受付後,「(社)ハイビジョン推進協会」として, 1991 年 10 月 15 日に設立が許可されている。
}

\section{3 ペイ・パー・ビュー研究会}

BS-3 b によるハイビジョン放送は, 当初は試験放 送としての位置づけであるが，いずれ本放送が始まる ことになろう．このときの有力な実用方法のひとつと して有料方式，特にペイ・パー・ビュー（Pay Per View：PPV) 方式が考えられている.PPV 方式は, 毎月一定額の課金方式(フラット)とは異なり，視聴実 績に応じて課金する有料方式である.

八イビジョン有料放送，とくにこの PPV 方式に重 点を置いて, 事業促進の立場から検討を行う「ハイビ ジョン・ペイ・パー・ビュー研究会」が設置されてい る.この研究会は, 放送事業者, ソフト制作者, メー 力, 料金回収代行業者, 銀行等の代表者から構成さ れ，(財) 衛星放送セキュリティセンターに事務局を置 いている. 1990 年 12 月から活動が開始され， 1 年間 の予定で, 様々な角度からの研究が進められている.

なお，(財) 衛星放送セキュリティセンターは, 衛星 による有料放送に必要な有料方式技術に関する調査研 究, 研究開発等を行うとともに, 有料放送システムに おける暗号の管理等のセキュリティ管理業務等を行 い,もって衛星放送の普及・発展に寄与することを目 的として, 1990 年 10 月に設立されたものである.

(1991 年 7 月 3 日受付)

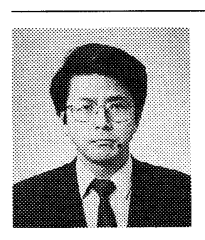

河贺整等昭和 53 年, 金沢大学大学院 工学研究科修士課程修了. 同年, 郵政省入 省. 昭和 61 年, 通信政策局国際企画課課長 補佐, 昭和 63 年, 放送行政局技術課長補佐 となり, 現在に至る.クリアビジョン,ファ クシミり放送等の技術開発推進・技術基準策 定, HDTV の国際規格問題に從事.

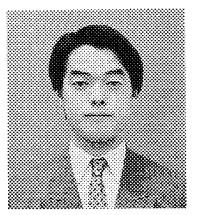
杉浦誠 昭和 59 年, 京都大学工学部 情報工学科卒業. 同年, 郵政省入省. 平成 3 年, 放送行政局衛星放送課課長補佐となり, 現在に至る。テレビジョン衛星放送, PCM 衛星放送, HDTV 衛星放送等の技術開発推 進, 技術基準の策定に従事。 